\title{
Remaining As A Leader or Not? Technology Spillover Answers
}

\author{
Wang Tsung-Li ${ }^{1}$ Hung-Pin Lin ${ }^{2} \&$ Yu-Chi Sung ${ }^{3}$ \\ ${ }^{1}$ Department of Marketing Management, Shu-Te University, Kaohsiung, Taiwan. \\ ${ }^{2}$ Department of International Business \& Trade, Shu-Te University, Kaohsiung, Taiwan. \\ ${ }^{3}$ Department of Leisure \& Tourism Management, Shu-Te University, Kaohsiung, Taiwan. \\ Correspondence: Hung-Pin Lin, Department of International Business \& Trade, Shu-Te University, Kaohsiung, \\ Taiwan.
}

Received: January 15, 2016

Accepted: January 31, 2016

Available online: February 4, 2016

doi:10.11114/aef.v3i2.1357

URL: http://dx.doi.org/10.11114/aef.v3i2.1357

\begin{abstract}
Much has been discussed about the advantages and disadvantages of being a first mover. However, discussion regarding the incentives encouraging a firm to remain as leader is absent in most studies. This paper aims to fill this gap and provide theoretical and empirical evidences vis-à-vis the incentives of remaining as a leader, by comparing profits between leader and follower when taking technology spillover and technological efficiency into consideration. The findings show that in regard to effective technological efficiency: (i) under the condition of a weak (strong) technology spillover, retaining the position of leader firm is (not) a dominant strategy because of higher (lower) profits than a follower; (ii) the half-shared technology spillover leads to an equal profit between firms, and implies a critical time of action for the leader firm to break the evenly-matched status by reconsidering first mover advantages; (iii) an empirical study on a data set of 352 high-tech and non-high-tech SMEs in manufacturing industry from 1999 until 2006 lends strong support to these results and may also provide useful clues for technology managers or practitioners to make better policies to benefit their market competitiveness.
\end{abstract}

Keywords: first mover advantage (disadvantage); technology investment; technological efficiency; technology spillover.

\section{Introducation}

Whether or not a firm should be a leader in its field is a controversial issue, especially when many executives assume that the first company in a new product category will acquire an unbeatable "head start" and reap long-lasting benefits, something that, in reality, does not always happen (Suarez and Lanzolla, 2005). Existing studies have documented the advantages and disadvantages of a first mover strategy. Such studies have indicated that this strategy leads to a series of competitive advantages (e.g. Chaffee, 1985; Kerin, et. al 1992). Previous literature has shown that there are several advantages for a first mover or leader firm. For example, an incumbent brand, in regard to brand loyalty, holds demand advantages over a later brand because consumer preference rests with the first brand that performs adequately (Schmalensee, 1982). Glazer (1985) suggested that first movers are more likely than their followers to have more extensive learning, and thus better access to opportunities. Patterson (1993) stressed that a first mover could initiate the build-up of experiential raw material, and hence, develop the most advanced insights, associations and causal maps within a specified context.

A first mover strategy may also lead to some other advantages. such as: establishing technological leadership (e.g. Kvint, 1994; Luo, 1995; Schnaars, 1994; Shenkar, 1990), preempting specialized assets, product or market positioning (e.g. Allen, 1993; Cohen and Levinthal, 1994), engaging in price skimming (e.g. Amir and Stepanova, 2006; Rhee, et. al, 1992; Rhee 2006), using the buyer switching costs to enhance its market share (e.g. Stigler and Becker, 1977), securing technological leadership of patents or R\&D technology (e.g. Hamel and Prahalad, 1994), controlling crucial or scarce resources for success in a competitive market (e.g. Kerin, et. al, 1992; Lilien and Yoon, 1990; Mascarenhas, 1992) and, finally, erecting a higher entry barrier for followers (e.g. Anderson and Engers, 1994; Kvint, 1994; Luo, 1995; Luo and Peng, 1998; Pan and Chi, 1999; Shenkar, 1990).

A first mover or leader can potentially maintain its competitive advantage via its technological lead, thus remaining superior to later entrants, or lose its pioneering position and first mover advantage, by being outperformed by later 
entrants (e.g., Robinson et. al, 1992; Kalyanaram, et. al, 1995; Pan and Chi, 1999; Robinson, et. al, 1995; Lieberman and Asaba, 2006). Gal-Or $(1985,1987)$ analyzed the disadvantages of being a leader, irrespective of whether both the first mover and later entrant were equally willing to assess demand through market research. Golder and Tellis (1993) reported that only 53\% of first movers survived in the market. Kalyanaram et al. (1995) also showed the same result and suggested that the market entry order is not necessarily related to long-term market performance.

First movers may take a higher risk than later entrants with respect to new product failure. Such risks relate to the forecasting bias for a pioneering brand, or to the inability to eliminate uncertainty in consumer acceptance of a pioneering innovation (Hamel and Prahalad, 1994). Because of the substantial costs linked to risk, being a later entrant may be more beneficial than being a first mover (Bryman, 1997). A later entrant is in a better position to learn more about customer needs by using a "wait-and-see" strategy and thus avoiding market uncertainty and the difficulties that a first mover faces in regard to adapting to a rapidly changing environment (e.g., Lieberman and Montgomery, 1998; Teece, 1986).

Being able to analyze the advantages and disadvantages of being a first mover is an important ability, allowing firms to make educated decisions about becoming a market leader or market follower. However, to the best of our knowledge, the incentives or motivation to encourage a firm to become a leader or reject the temptation is absent in most studies. By constructing a model of Cournot duopoly competition and utilizing empirical evidence from a panel data analysis, this paper aims to fill this gap and provide a more complete understanding of a resolution of disputes vis-à-vis first mover advantages and disadvantages, when technology spillover is introduced. The role of technology spillover in the market environment can act as the leader firm's intellectual property right, being secured through patents, copyrights, or government conferred status; thus imitation or free-ride action from followers can be detected through realizing the degree of technology spillover (Bernstein and Nadiri 1989; Bloom et al., 2005).

Above all, in order to for a leader firm to maintain its position, a weak technology spillover may encourage the leader firm to expand its innovative activities, which in turn would lead to better technological efficiency and greater profit. Taking technology spillover into consideration not only helps innovation managers make better decisions with respect to technological efficiency, but also provides additional benefits with respect to profit expectations. In addition, our theoretical and empirical analyses also provide clues as to why leaders are motivated to keep their leading position or to let it go.

The remainder of this paper is structured as follows: In Sections 2 and 3, we outline in greater detail key characteristics of each of the first mover's advantages and disadvantages; in Sections 4 and 5, we use the key concepts and analyze the main parts of the theoretical model. In Section 6, we provide empirical evidence to sustain the theoretical propositions. Conclusions and policy implications are discussed in Section 7.of a manuscript opens with an introduction that presents the specific problem under study and describes the research strategy. Because the introduction is clearly identified by its position in the manuscript, it does not carry a heading labeling it the introduction. Before writing the introduction, consider the following questions (Beck \& Sales, 2001):

\subsection{First Mover Advantages}

\subsubsection{Technological Leadership}

Leadership in technological development is often synonymous with rapid technological progress, displaying advanced learning processes, or achieving success in patent or R\&D competition. Innovation that embodies proprietary R\&D technology may bestow the benefit of a timing advantage, but only if the leader has made product advances and has succeeded in securing intellectual property rights, copyrights, or trade secrets. Besides this, the learning process optimizes unit production costs in conjunction with cumulative output, and generates a sustainable cost advantage for an early or incumbent firm to maintain leadership in its market share. R\&D technology and preemptive patents also help a leader firm dominate R\&D strategy and build entry barriers that deter rivals from entering patent competition.

\subsubsection{Preemption of Specialized Assets}

Preemptive assets build up incentive confidence for the first movers: they believe that latecomers will be unprofitable in occupying second place. These assets may be physical resources that already exist, often in conjunction with scarce spatial resources (e.g., geographic space, product space, shelf space, etc.). These assets are useful and relate to technology investment and accumulated innovation, such as with advanced manufacturing facilities for nanometer processes and semiconductor technologies, or with unique upstream distribution channels. Preemptive technology investment in plant and equipment crystallizes an incumbent firm's profits in the market because such investment can serve as a first mover advantage that threatens and deters the potential second mover from joining the market (see Allen, 1993; Cohen and Levinthal, 1994). The first-mover can also select the most competitive niches, to limit the amount of space available for potential entrants.

\subsubsection{Buyer switching costs}


Competitive timing advantages related to switching costs constitute another first mover advantage. Once the leader firm (i.e. first mover) has acquired a customer base, it has an advantage over later entrants, because these customers may find it expensive to switch to a new product in terms of transaction costs, search costs or learning costs. For example, some end-users who have grown accustomed to a single, familiar word-processing or software program may not be willing to invest time in adopting a new one. This means that a late entrant must invest extra costs or resources to attract customers away from the leader firm.

\subsection{First Mover Disadvantages}

The mechanisms that benefit a leader firm may also present various disadvantages. These disadvantages may imply second mover advantages.

\subsubsection{Free-rider Effect}

The ability to "free-ride" on a leader firm's technological investment, taking advantage of any strong technology spillover, is an option that is sometimes available to the second mover. For some products and services, any productivity realized by the leader firm as it proceeds down the learning curve is also made available to the second mover due to the fact that imitation costs are much lower than technology costs (Lieberman, 1987; Lieberman and Montgomery, 1988; Utterback, 1994). One example is Amazon.com, launched in 1995 and, today, one of the world's largest online bookstores. However, Books.com was actually founded in 1991 and launched online in 1992. To date, it is considered the first known online bookstore. Amazon.com availed itself of second mover advantages. It found that web usage had increased 200\% each year in the previous few years, so it began to advertise its web-based business at over 28,000 other internet sites. It has since dominated the business; while the Amazon.com brand name is instantly recognizable, Books.com is much less so.

\subsubsection{Technological or Market Uncertainty}

A second mover knows that early entry into an uncertain market involves a high degree of risk, so it acts quickly to gain an advantage once the uncertainty has been resolved (see Olausson and Berggren 2010). If there are no clear advantages displayed by the first mover, the risks involved may reduce the willingness of firms to introduce new technology until the uncertainty has been mitigated.

\subsubsection{Incumbent Inertia}

A first mover may lose its leading position and be outpaced by a second mover when breakthrough innovations happen. The inertia that causes loss of leadership can be derived from several factors or circumstances. For example the first mover (i.e. the incumbent firm) may be too controlled by a specific set of fixed assets, be reluctant to cannibalize its own production line, or demonstrate weak technological efficiency. These factors make the first mover become more organizationally inflexible, which can inhibit its ability to respond quickly to environmental changes or exogenous threats.

After reviewing and understanding first mover advantages and disadvantages, the reasons or incentives for a firm to retain or release its position as a market leader is, to the best of our knowledge, absent in most studies. This paper aims to fill this gap and provide a brief review of pertinent concepts regarding the "technology spillover" perspective of a firm's strategy in the following section, which details theoretical and empirical evidence.

\subsection{Technomogy Spillover Perspective and First/Second Mover Advantages}

\subsubsection{Strong Technology Spillover}

Technology spillover is an external innovative activity, whereby information of a firm's ongoing innovative activity leaks to its competitors. Such information can benefit competitors by improving their efficiency in searching for innovation. Bloom et al. (2005) proposed that firm performance is affected by two countervailing "spillovers": a positive effect from technology spillovers and negative business effects from market rivals stealing. In general, the closer the firms are to one another (including geographically, technically, or in terms of product differentiation), the greater the technology spillover (for example, see Amir, 2000; Carlino, 2001, Jovan, 2012). Hence, each firm has incentives to restrict its technology expenditure and await an opportunity to imitate, thereby availing itself of a second mover's advantages. The ability to "free-ride" on a leader firm's technology investment, which includes any strong technology spillover, is sometimes available to the second mover.

For some products and services, any productivity realized by the leader firm as it proceeds down the learning curve is also made available to the second mover due to the fact that imitation costs are much lower than technology costs (Lieberman, 1987; Lieberman and Montgomery, 1988; Utterback, 1994). For example, Tellis and Golder (1996) showed that in many cases, the firms that dominated the market were not the first movers but the second movers into the market. It can be conjectured that due to the strong spillover effect from the first movers, second movers are able to minimize trial and error by accessing information through the observation of the first movers' experiences or technological 
activities.

\subsubsection{Weak Technology Spillover}

If a technology expenditure leads to a very high spillover, intellectual property rights can often be used to temporarily maintain the profitability of a first mover's ideas; these rights can be secured through patents, copyrights, scarce resources, or governmental protection (e.g. Kerin, et al., 1992; Lilien and Yoon, 1990; Mascarenhas, 1992). With such protections, the technology spillover is made extremely weak, even when firms are intense rivals. A state of weak spillover prevents exploitation by rival firms. In such cases, a firm that is a technological leader has incentives to expand its innovative activities and maintain its first mover advantages. Lerner (2002) and Moser (2005) found that a weak technology spillover (i.e. a sound patent system) may stimulate R\&D and innovation. Additionally, Lanjouw and Cockburn (2000) and Arora et al. (2008) showed that innovations are concentrated in some indicated industries once the technology spillover is relatively weak, thus imitation can be easily detected. Therefore, it can be argued that the degree of technology spillover plays an important role in agents' decision on the timing investment of their activities.

Much of the current literature that deals with the crucial factor, technology spillover, does not provide an answer as to how much technology spillover is involved in deciding whether or not to choose a leader or follower position. A firm may focus only on the learning or imitating aspect of the first mover or second mover advantage without considering the timing of when to be a leader or a follower. In this paper we construct a simple Cournot duopoly model according to D'Aspremont and Jacquemin (1988). Together with technological efficiency, it is considered able to illustrate why a firm should continue to retain a position of leader in order to maintain its first mover advantages, while expecting weak spillover and dominating profit. On the other hand, we also prove that a leader firm may be unprofitable and inferior to a follower when first mover disadvantages and strong technology spillover are expected. These findings are also consistent with our empirical evidence where leader firms in high-tech and follower firms in non-high-tech SMEs manufacturing industries are studied.

\section{Method and Model: Cournot Duopoly Competition}

In a Cournot duopoly competition, it is supposed that there are two firms: Firm 1 is the leader and Firm 2 is the follower. The linear demand of homogeneous production is specified as $p=a-b\left(q_{1}+q_{2}\right)$, and the decision variables of technology investment are $x_{i}$ for Firm $i, i=1,2$. The constant unit cost of production $c_{i}$ depends on $x_{i}$, which takes the form of $c_{i}=c-\left(x_{i}+\beta x_{j}\right) i, j=1,2, i \neq j$. For simplicity, we discuss the conditions of technology spillover briefly, as weak spillover $(\beta \rightarrow 0)$, half-shared spillover $(\beta \rightarrow 0.5)$ and strong spillover $(\beta \rightarrow 1)(\mathrm{Griliches}, 1979$, Bernstein and Nadiri, 1983 and Qiu, 1997). Firm $i$ 's technology cost is quadratic and given by: $\frac{1}{2} \gamma x_{i}^{2}$. The coefficient $\gamma$ captures technology efficiency which measures the extent to which technology investment $(x)$ contributes to firm's profit $(\pi)$, and notes that the lower the value of $\gamma$, the better the technological efficiency that is achieved in a firm's profit function.

Firms choose their respective levels of technological investment, and the leader chooses the best R\&D investment (i.e. one that maximizes profit based on the follower's best R\&D investment response function, see Smith, 2006, Hartmann et al., 2006, Mitchell and Hamilton, 2007, and Tubbs, 2007). Solving by backward induction, we examine whether the leader has a first profit advantage by taking the technology investment plan $\left(x_{1}\right)$ based on his rival's response in the first stage. Beginning with the second stage, firms choose output $q_{i}$ to maximize profit. We then have the Cournot-Nash equilibrium output and profits denoted as $q_{1}(x, \beta), q_{2}(x, \beta)$ and $\pi_{1}(x, \beta), \pi_{2}(x, \beta)$, respectively.

In the first stage, Firm $i$ chooses $x_{i}$ to maximize its profit:

$$
\pi_{i}(x, \beta)=\left(a-b\left(q_{i}(x, \beta)+q_{j}(x, \beta)\right)-c+x_{i}+\beta\right) q_{i}(x, \beta)-\frac{1}{2} \gamma x_{i}^{2} .
$$

The following two first-order conditions of Equation (1) become:

$$
\partial \pi_{1} / \partial x_{1}=0, x_{1}=R_{1}\left(x_{2}\right) \text { and } \partial \pi_{2} / \partial x_{2}=0, x_{2}=R_{2}\left(x_{1}\right) \text {, where } a-c=A>0 .
$$

Because we suppose that Firm 1 is the leader and Firm 2 the follower, Equation (2) expresses the R\&D best response function as $R_{i}\left(x_{j}\right)$ of both Firms 1 and 2. To derive the equilibrium, in the second stage, we substitute Firm 2's reaction function $R_{2}\left(x_{1}\right)$ into Firm 1's profit function $\pi_{1}(x, s)$, whereupon we maximize the first-order condition of $x_{1}$ to obtain $x_{1}(\beta, \gamma)$ and $x_{2}(\beta, \gamma)$ by substituting $x_{1}^{*}(s, \gamma)$ into Firm 2's technology best response function $R_{2}\left(x_{1}\right)$, we then have $x_{2}^{*}(\beta, \gamma)$. Inserting $x_{1}(\beta, \gamma)$ and $x_{2}(\beta, \gamma)$ into both firms' profit function yields the final profit of Firms 1 and 2, as denoted by $\pi_{1}(\beta, \gamma)$ and $\pi_{2}(\beta, \gamma)$, respectively. The best method by which to determine whether Firm 1 prefers to remain as a leader is to compare its profit to that of Firm 2 $\left(\pi_{1}(\beta, \gamma)-\pi_{2}(\beta, \gamma)\right)$. For simplicity, we discuss our noted conditions of weak spillover $(\beta \rightarrow 0)$, half-shared 
spillover ( $\beta \rightarrow 0.5$ ), and strong spillover $(\beta \rightarrow 1)$ in the following propositions.

2.1 Proposition 1: Retain the position of leader: Competitively higher profit with weak technology spillover $(\beta \rightarrow 0)$ and higher technological efficiency.

Proof of Proposition 1:

Note that the profit comparison with a weak technology spillover between the leader and the follower is given by:

$$
\left.\left(\pi_{1}-\pi_{2}\right)\right|_{\beta \rightarrow 0}=48 b A^{2} \gamma^{2}(1-b \gamma)(4-3 b \gamma) / \theta_{1}
$$

Equation (3) shows that the incentive for the leader to maintain its position as market leader is verified as $\pi_{1}>\pi_{2}$, when $\gamma<4 /(3 b)$. Intuitively, $\beta \rightarrow 0$ indicates a weak technology spillover and implies that a firm benefits only from its own technology investment in cost reduction. Hence, whether Firm 1, as a market leader, should retain its position of market leader depends on the degree of $\gamma$ regarding a weak technology spillover. Recalling that technological efficiency $(\gamma)$ represents how much technology investment $(x)$ contributes to Firm 1's profit $\left(\pi_{1}\right)$, it is noted that the lower value of $\gamma$ indicates that better technological efficiency is achieved in Firm 1's profit function. On the other hand, weak technology spillover shows that as long as the degree of $\gamma$ is sufficiently small $(\gamma<4 /(3 b))$, the technological efficiency will be effective, as Firm 1 has a strong incentive to maintain its position as market leader due to its having higher profit than Firm 2.

Insights gained by this result are straightforward, in that weak technology spillover in the market environment implies that a leader firm's intellectual property right can often be secured through patents, copyrights, or government protection; thus imitation or free-ride action from a follower can be easily detected. Such weak technology spillover guarantees the first mover advantages and encourages the leader to expand its innovative activities, which in turn leads to better technological efficiency and profit competence. Thus, this result encourages the leader to maintain its leading position.

\subsection{Proposition 2: Critical time for action: half-shared technology spillover $(\beta \rightarrow 0.5)$}

Proof of Proposition 2:

The profit comparison with a half-shared technology spillover between the leader and the follower is given by

$$
\left.\left(\pi_{1}-\pi_{2}\right)\right|_{\beta \rightarrow 0.5}=0
$$

When the degree of spillover is half-shared, it means that each firm gets "half" the benefits from the other's investment in cost reduction, and half from its own. This result has no bearing on whether one should retain a position as market leader or become a follower, no bearing on technological investment, because the firms have the same profits $\left(\pi_{1}=\pi_{2}\right)$, and nothing to do with technological efficiency $(\gamma)$. However, even though there may be no difference in acting as a market leader, the half-shared technology spillover and the equal profit between firms implies that once the external competitive environment has changed, it will be a critical time of action for the leader firm (or follower firm) to either change direction or remain the same in order to gain competitive advantage.

The insight gained here is usually as a result of duopoly competition, especially with firms that could be labeled as "evenly matched." Once one of the firms has a technological lead on its rival, it is a critical time of action for the leader firm to break the evenly-matched status and thus eventually gain a profit advantage.

\subsection{Proposition 3: Giving up being a leader: Competitively lower profit with strong technology spillover $(\beta \rightarrow 1)$} even with higher technological efficiency

Proof of Proposition 3:

The profit comparison with a strong technology spillover between the leader and the follower is given by:

$$
\left.\left(\pi_{1}-\pi_{2}\right)\right|_{\beta \rightarrow 1}=8 A b^{2} \gamma^{3}(9 b \gamma-1) / \theta_{2}
$$

Equation (5) shows that this condition is verified as $\pi_{1}<\pi_{2}$, when $\gamma<1 /(9 b)$. Intuitively, $\beta \rightarrow 1$ indicates that each firm benefits as much from the other firm's investment in technology cost reduction plans as from its own. Both Firm 1's and Firm 2's technology cost reduction plans are expressed by $x_{1}+x_{2}$; hence, leader profitably is determined solely by the degree of $\gamma$. As with proposition 1, evidence in Equation (5) shows that a strong technology spillover and a sufficiently small degree of $\gamma$ (i.e. $\gamma<1 /(9 b))$ implies that even though the technological efficiency remains effective, Firm 1 as a leader has no incentive to maintain its first mover position. This is because staying as a leader ultimately derives a competitively "lower" profit than that of Firm 2, by virtue of being the first to make a technology investment plan. This result will lead Firm 1 to reexamine the first mover disadvantage and make Firm 1 consider abdication of its leadership.

The insight from this result is straightforward. A strong technology spillover in the market environment implies that the ability to "free-ride" on a leader firm's technology investment is sometimes available to the follower. For some products 
and services, any productivity realized by the leader firm is also made available to the second mover due to the fact that imitation costs are much lower than technology costs (Lieberman, 1987; Lieberman and Montgomery, 1988; Utterback, 1994). One good duopoly example in the market, as introduced by Zhang and Markman (1998), is the case of web browser competition. Netscape was the first mover in the web browser market, while Internet Explorer was the follower. Despite Netscape's technological efficiency being initially superior to that of Internet Explorer, the strong technology spillover allowed Internet Explorer to have features that Netscape did not have.

\subsection{Empirical Discussion}

Propositions 1 and 3 can both be tested by empirical cases. We use the data of high-tech and non-high tech small and medium-sized enterprises (SMEs) in the manufacturing industry to measure the significance of technological efficiency and technology spillover in the profit growth between leaders and followers. Panel data models including random and fixed effect are applied because they have the following advantages over traditional OLS regression models: (i) greater control of possible collinearity; and (ii) better explanation power caused by the absence of relevant independent variables to explain the dependent variables.

To estimate the regressions, the dynamic panel of the technology spillover-profit model can be expressed in the following log-linear form:

$$
\ln \Delta \pi_{i, t}^{k}=\alpha_{0}+\alpha_{1} \ln S_{i, t}^{k}+\alpha_{2} \ln E_{i, t}^{k}+\varepsilon_{i, t},
$$

where $k \in h, n h$ represents the high-tech and non-high-tech SMEs industry, respectively. $\ln \Delta \pi_{i, t}^{k}$ measures the difference between the logarithm to firm sales in the present period and the logarithm to firm sales in the previous period; $\ln S_{i, t}^{k}$ is the logarithm of technology spillover; $\ln E_{i, t}^{k}$ is the logarithm of technological efficiency which identifies the ratio of the R\&D investment to total sales; $\varepsilon_{i, t}$ is the error term. Based on the above considerations, we formulate the following hypotheses:

Hypothesis 1: Retain the position of leader: Weak technology spillover and higher technological efficiency lead to a leader firm's greater profit growth.

Hypothesis 2: Retain the position of follower: Strong technology spillover and higher technological efficiency lead to a follower firm's greater profit growth.

\subsection{Data source and definitions of technology spillover}

This study uses the Iberian Balance Sheet Analysis System (SABI) database, from 1999 to 2006, provided by Bureau van Dijk. High-tech and non-high-tech SMEs in the manufacturing industry are selected according to the criteria of OECD classification (2002) and Based on the OECD classification (2002), high-tech sectors are aerospace, computers, office machinery, electronics-communications, pharmaceuticals and scientific instruments. Non-high-tech sectors including the medium-high technology and low technology sectors are: chemicals, electrical machinery, fabricated metal products, food, beverages and tobacco, motor vehicles, non-electrical machinery, non-ferrous metals, non-metallic mineral products, paper and printing, petroleum refining, rubber and plastic products, shipbuilding, textiles and clothing, transport equipment, and wood and furniture. We suppose that most of the incumbent firms for the entire period (1999-2006) take the first mover advantage and act as leader firms; most of the firms entering during the period (1999-2006) are follower firms. The summarized sample description is presented in Table 1.

Table 1. Sample description

High-tech SMEs $\quad$ Non-high-tech SMEs

Incumbent firms in all period (leaders)

Firms entering in the period (followers)

Total number of SMEs

Total number of observations
71

28

99
497

148
208

45

253

Following Spence (1984) and Raut (1995), the technology spillover $S_{i k}$ of firm $i$ in $k$ industry can be expressed by:

$$
S_{i k}=\sum R_{j k} \quad, \quad j \neq i
$$


where $\sum R_{j k}$ is the R\&D capital calculated by the discounted sum of the past $\mathrm{R} \& \mathrm{D}$ investment stream of firm $j$ in $k$ industry when the R\&D capital of firm $i$ is excluded, and we choose the value of the discounted rate as 0.85 as adopted by Griliches and Mairesse (1983), and Cuneo and Mairesse (1984).

\section{Results}

Tables 2 and 3 present the results of the panel data model regarding the profit growth determinants between leaders and followers in high-tech and non-high-tech SMEs firms; we have taken into consideration the fixed and random effects model among technology spillover, technological efficiency and profit growth.

The empirical analysis presented in Table 2 indicates the following regarding leader firms in high-tech SMEs manufacturing industry: (i) the Hausman test below the 5\% significance level suggests that the fixed effect model should be selected because that Table 2 shows that the null hypothesis is rejected in our panel data; therefore, the fixed effect model is selected in the leader firms' profit regression model; (ii) Below the 5\% significance level, the null of hypothesis yields coefficient (t-statistics) value of 4.31(2.20) which shows that the relationship between the profit growth ( $\ln \Delta \pi_{i, t}^{h}$ ) and technological efficiency $\left(\ln \Delta E_{i, t}^{h}\right.$ ) is positive and statistically significant; (iii) Below the $1 \%$ significance level, the null of hypothesis yields coefficient (t-statistics) value of -0.43(-3.27) which shows the relationship between the profit growth $\left(\ln \Delta \pi_{i, t}^{h}\right)$ and technology spillover $\left(\ln \Delta S_{i, t}^{h}\right)$ is negative and statistically significant. Based on (ii) and (iii), we find that Proposition 1 in our theoretical model and Hypothesis 1 are both sustained by our empirical evidence.

Table 2. Leader firms' profit growth, technology spillover, and technological efficiency

\begin{tabular}{|c|c|c|c|c|}
\hline \multirow[b]{3}{*}{$\ln \Delta S_{i, t}^{h}$} & \multicolumn{2}{|l|}{ High-tech SMEs } & \multicolumn{2}{|c|}{ Non-high-tech SMEs } \\
\hline & \multicolumn{2}{|c|}{ Dependent variable: $\ln \Delta \pi_{i, t}^{h}$} & \multicolumn{2}{|c|}{ Dependent variable: $\ln \Delta \pi_{i, t}^{n h}$} \\
\hline & $-0.43(-3.27)^{* * *}$ & $-3.06(1.02)$ & & \\
\hline $\ln \Delta E_{i, t}^{h}$ & $4.31(2.20)^{* *}$ & $0.03(1.98)^{*}$ & & \\
\hline $\ln \Delta S_{i, t}^{n h}$ & & & $-0.31(-2.27)^{* *}$ & $-0.88(-1.08)$ \\
\hline $\ln \Delta E_{i, t}^{n h}$ & & & $1.01(1.44)$ & $1.02(2.27)^{* *}$ \\
\hline Hausman Test & $x_{h}^{2}(2)=8.48 * *$ & & $x_{n h}^{2}(2)=2.4$ & \\
\hline$R^{2}$ & 0.88 & 0.78 & 0.90 & 0.81 \\
\hline Adjusted $R^{2}$ & 0.85 & 0.74 & 0.87 & 0.78 \\
\hline
\end{tabular}

(a) The regression model is $\ln \Delta \pi_{i, t}^{k}=\alpha_{0}+\alpha_{1} \ln S_{i, t}^{k}+\alpha_{2} \ln E_{i, t}^{k}+\varepsilon_{i, t}, i \in$ leader firms .

(b) The number inside the parentheses is the $t$-statistics.

(c) $* * *, * *$, and $*$ represents that the $1 \%, 5 \%$ and $10 \%$ significance level, respectively.

(d) The critical value of $x_{i}^{2}$ (2) for $1 \%, 5 \%$ and $10 \%$ significance level are 9.21, 5.99, and 4.61, respectively.

(e) (+) marks the appropriate model which selected through Hausman test.

In turn, Table 3 indicates the following regarding follower firms in non-high-tech SMEs manufacturing industry, (i) the Hausman (1978) specification test in Table 3 shows that the null hypothesis is not rejected in our panel data; therefore, the random effect model is selected in follower firms' profit regression model; (ii) the relationship between the profit growth $\left(\ln \Delta \pi_{i, t}^{n h}\right)$ and technological efficiency $\left(\ln \Delta E_{i, t}^{n h}\right.$ ) is positive and statistically significant (notes that below the $1 \%$ significance level, the null of hypothesis yields coefficient (t-statistics) value of 1.62(3.47); (iii) the relationship between the profit growth $\left(\ln \Delta \pi_{i, t}^{n h}\right)$ and technology spillover $\ln \Delta S_{i, t}^{n h}$ is positive and statistically significant (notes that below the 5\% significance level, the null of hypothesis yields coefficient (t-statistics) value of 1.07(1.98).). On the basis of the empirical evidence (ii) and (iii), we find that with a higher technological efficiency, the strong technology spillover helps the follower to obtain better profit growth; therefore, proposition 3 and Hypothesis 2 are both sustained by our empirical evidence. 
Table 3. Follower firms' profit growth, technology spillover, and technological efficiency

High-tech SMEs

Non-high-tech SMEs

Dependent variable: $\ln \Delta \pi_{i, t}^{h}$

Dependent variable: $\ln \Delta \pi_{i, t}^{n h}$

\begin{tabular}{llccc}
\hline $\ln \Delta S_{i, t}^{h}$ & $-1.55(-2.21)^{* *}$ & $1.74(-1.39)$ & & \\
$\ln \Delta E_{i, t}^{h}$ & $3.54(1.08)$ & $2.03(1.78)^{*}$ & & \\
$\ln \Delta S_{i, t}^{n h}$ & & & $-2.71(-1.79)^{*}$ & $1.07(1.98)^{* *}$ \\
$\ln \Delta E_{i, t}^{n h}$ & & $2.43(1.52)$ & $1.62(3.47)^{* * *}$ \\
\hline \multirow{2}{*}{ Hausman Test } & $x_{h}^{2}(2)=3.52$ & & $x_{n h}^{2}(2)=1.23$ & \\
$R^{2}$ & 0.76 & 0.88 & 0.84 & 0.80 \\
Adjusted $R^{2}$ & 0.69 & 0.78 & 0.72 & 0.71 \\
\hline
\end{tabular}

(a) The regression model is $\ln \Delta \pi_{i, t}^{k}=\alpha_{0}+\alpha_{1} \ln S_{i, t}^{k}+\alpha_{2} \ln E_{i, t}^{k}+\varepsilon_{i, t}, i \in$ follower firms .

(b) The number inside the parentheses is the $t$-statistics.

(c) $* * *, * *$, and $*$ represents that the $1 \%, 5 \%$ and $10 \%$ significance level, respectively.

(d) The critical value of $x_{i}^{2}$ (2) for $1 \%, 5 \%$ and $10 \%$ significance level are 9.21, 5.99, and 4.61, respectively.

(e) (+) marks the appropriate model which selected through Hausman test.

\section{Discussion}

There have been many discussions concerning first mover advantages and disadvantages. However, to the best of our knowledge, the reasons why a firm should either retain or surrender its position as market leader are absent in most studies. This paper aimed to fill this gap; it finds that, in Cournot's duopoly competition, the crucial factors of technology spillover and technological efficiency both play important roles in determining a leader firm's leading position and strategy. First, we show that despite the effectiveness of technological efficiency (i.e. the technology investment plan is beneficial to profit), strong technology spillover makes a leader firm decide to give up its leader position because of lower profit than that of the follower firm. Second, we show that weak technology spillover guarantees the effectiveness of technological efficiency and enables a leader firm to retain its position as market leader because of a higher profit than that of the follower firm. Finally, we show that half-shared technology spillover leads to an equal profit between firms, but implies that it is a critical time of action for the leader firm (or follower firm).

These theoretical results are also supported by the empirical evidence through a panel data of high-tech and non-high-tech SMEs of the manufacturing industry investigation. They may also provide useful clues or criterion for technological practitioners or managers to make better policies to benefit their market competitiveness.

\subsection{Implications for practitioners}

Technological practitioners should also be interested in the role that technology spillover plays, as evidenced in the theoretical and empirical results we have presented, and may well be interested in the relevant application to technology and customer needs.

\subsubsection{When customer needs lead and technology follows}

It can be noted, as shown in the presentation with regard to the mechanism of technological competition, that being a leader and having weak technology spillover will result in profitable outcomes. By examining the essence of a leader's technological competition and profits, it can be deduced that one of the reasons that profits are made is that a greater market demand can be derived from an expansion of customer needs. Technological practitioners seeking to grow their businesses and maintain their respective leader positions are advised to test the market in advance to measure its innovation costs. Accordingly, once market demand increases, weak technology spillover means the leader firm is free from the follower's "free-ride" or imitation; thus, effective technological efficiency may contribute to the profit and market share. 


\subsubsection{When technology leads and customer needs follow}

Technological practitioners may wonder what would happen if technology were updated at an explosive pace, while there was a slow response regarding customer needs. This has been answered by our theoretical and empirical analyses which show that being a follower with strong technology spillover will result in profitable outcomes. Accordingly, being a follower may be a good alternative for technological practitioners, given that being a leader no longer guarantees positive economic profits, especially when customer needs are receding. Moreover, once market uncertainty arises as a result of an instability in customer needs, a firm may wish instead to be a follower and wait for a higher technology spillover (i.e. free rider effect), as suggested by the first mover disadvantages.

\subsection{Implications for innovation managers}

In the presentation of this paper, our focus has been on the degree of technology spillover, as evidenced by having either first mover advantages or disadvantages. Our theoretical and empirical evidence have all been related to this. Profit expectation is the key incentive in deciding whether or not to remain as leader. We conclude with a brief discussion of managerial implications for innovation managers.

The innovation managers of a firm are those who decide whether or not to stay as a market leader. They must, when a specific investment opportunity arises, evaluate the decision value and estimate the profit difference between first mover advantages and disadvantages. There are several issues pertaining to the position of a "pioneer," and each must be considered by innovation managers.

The first issue is concerned with how a first mover firm can maintain both its profits and its leader advantages. How can a first mover firm protect itself from a second mover's imitation, the free-rider problem, or a strong technology spillover? Some evidence within this study suggests that patents, copyrights, scarce resources and other governmental protection are obvious ways of acquiring weak technology spillover and guaranteeing the first mover firm's dominant profit advantage in the market. Strong patent protection implies a low possibility of imitation and a weak technology spillover between first and second movers.

Second, innovation managers must remain aware of the incumbent inertia phenomenon to prevent them from making the wrong decisions when suffering from the exogenous impact of environmental changes. In general, weaker technology spillover usually exists in a firm with incumbent inertia. If the incumbent firm realizes that the market has very weak technology spillover, then weaker technology spillover will lead to greater arrogance on the part of the incumbent. Golder and Tellis (1993) report that only 53\% of first mover firms survive in the market; such results warn innovation managers that succumbing to incumbent inertia may lead to slower technological efficiency, greater neglect of customer needs and the opening of a window of opportunity for potential entrants. As a result, innovation managers may wish to place greater value on information pertaining to the development of new technology, and wish to know how organizations strengthen innovation and broaden product lines to adapt to environmental changes.

Third, with respect to strong profit and market-share competition, innovation managers of first mover firms should consider that once a leading technology is introduced to the market, it is best to increase the firm's capacity to seize and exploit the first mover advantage. This is especially true in fast-growing markets, and helps prevent the potential threat of market share loss to ambitious second movers. Moreover, when a first mover firm has measured its technology investment, capacity and customer requirements adequately within the appropriate market niches, it appears that setting a formidable entry barrier to late entrants will help ensure the profit advantage of a first mover firm.

Finally, the theoretical evidence in this paper shows that a half-shared technology spillover effect will result in an "evenly-matched" condition, regardless of whether or not the technological efficiency is effective. In general, this game essentially becomes a stalemate that quickly becomes a "prisoners' dilemma". The label "prisoners' dilemma" is a canonical case of a game marked in game theory that shows why two individuals may not cooperate, even if it appears that it is in their best interest to do so. It is exemplified in a situation in which two entities could gain important benefits from cooperating or suffer from the failure to do so, yet find it merely expensive to coordinate their activities to achieve cooperation. However, it is an opportune time to take action for innovation managers to break the "evenly-matched" condition. To break through the zero-profit problem, innovation managers can protect their technology "know-how," enhance their patent rights, improve their technological efficiency and broadcast product differentiations. Once the firm deviates from this "match game" by enacting any technology breakthroughs, a profitable policy expectation becomes more feasible.

\section{References}

Allen, B. (1993). Capacity pre-commitment as an entry barrier for price-setting firms. International Journal of Industrial Organization, 11(1), 63-72. http://dx.doi.org/10.1016/0167-7187(93)90036-C 
Amir, R. (2000). Modeling imperfectly appropriable R\&D via spillovers. International Journal of Industrial Or ganization, 18(7), 1013-1032. http://dx.doi.org/10.1016/S0167-7187(00)00071-0

Amir, R., \& Stepanova A. (2006). Second-mover advantage and price leadership in Bertrand duopoly. Games and Economic Behavior, 55(1), 1-20. http://dx.doi.org/10.1016/j.geb.2005.03.004

Anderson, S. P., \& Engers, M. (1994). Strategic investment and timing of entry. International EconomicReview, 35(4), 833-853. http://dx.doi.org/10.2307/2527000

Arora, A., Ceccagnoli M., \& Cohen W. M. (2008). R\&D and the patent premium. International Journal of In dustrial Organization, 26(5), 1153-1179. http://dx.doi.org/10.1016/j.ijindorg.2007.11.004

Bernstein, J. I., \& Nadiri M. I. (1983). Does knowledge intensity matter? A dynamic analysis of research and development, utilization and labor requirements. NBER Working Paper, 1238.

Bernstein, J. I., \& Nadiri M. I. (1989). Research and development and intra-industry spillovers: an empirical a pplication of dynamic duality. Review of Economic Studies, 56(2), 249-69. http://dx.doi.org/ 10.2307/2297 460

Bloom, N., Schankerman M., \& Reenen J. V. (2005). Identifying technology spillovers and product market riv alry. CEPR Discussion Paper, 4912.

Bryman, A.. (1997). Animating the pioneer versus late entrant debate: An historical case study. TheJournal of Management Studies, 34(3), 415-438. http://dx.doi.org/10.1111/1467-6486.00057

Carlino, G. A. (2001). Knowledge spillovers: cities' role in the new economy. Business Review, 4(4), 17-26. ht tp://dx.doi.org/10.1007/s11365009-0129-0

Chaffee, E. (1985). Three models of strategy. Academic of Management Review, 10(1), 89-98. http://dx.doi.org/ 10.5465/AMR.1985.4277354

Cohen, W. M., \& Levinthal D. A. (1994). Fortune favors the prepared firm. Management Science, 40(2), 227251. http://dx.doi.org/10.1287/mnsc.40.2.227

Cuneo, P., \& Mairesse J. (1984). Productivity and R\&D at the firm level in French manufacturing. University of Chicago Press, Chicago, 375-392.

D’Aspremont, C., \& Jacquemin, A. (1988). Cooperative and non-cooperative R\&D in duopoly with spillovers. American Economic Review, 82(5), 1293-1306.

Gal-Or, E. (1985). First mover and second mover advantages. International Economic Review, $26(3), 649-653$.

Gal-Or, E. (1987). First-mover disadvantages with private information. Review of Economic Studies, 54(2), 279 -292. http://dx.doi.org/10.2307/2297517

Glazer, A. (1985). The advantages of being first. American Economic Review, 75(3), 473-480. http://dx.doi.org/ $10.2307 / 1814812$

Golder, P. N., \& Tellis G. J. (1993). Pioneer advantage: marketing logic or marketing legend ? Journal of M arketing Research, 30(2), 158-170. http://dx.doi.org/10.2307/3172825

Griliches, Z. (1979). Issues in assessing the contribution of R\&D to productivity growth. Bell Journal of Econ omics, 10(1), 92-116. http://dx.doi.org/10.2307/3003321

Griliches, Z., \& Mairesse J. (1983). Comparing productivity growth: An exploration of French and U.S. indust rial and firm data. European Economic Review, 21(1-2), 89-119. http://dx.doi.org/10.3386/w0961

Hamel, G., \& Prahalad C K. (1994). Competing for the Future. Harvard Business School Press, Boston.

Hartmann, G., C., Myers M. B., \& Rosenbloom R. S. (2006). Planning your firm's R\&D investment. Researc h-Technology Management, 49(2), 25-36. http://dx.doi.org/10.1080/08956308.2006.11657366

Hausman, J., A. (1978). Specification tests in econometrics. Econometrica, 46(6), 1251-1271. http://dx.doi.org/1 $0.2307 / 1911406$

Jovan F., Srečko, D., \& Goran P. (2012). Knowledge based economy: the role of expert diaspora. Panoecono micus, 59(3), 369-386. http://dx.doi.org/10.2298/PAN1203369F

Kalyanaram, G., Robinson W. T., \& Urban G. L. (1995). Order of entry: established empirical generalizations, emerging empirical generalizations, and future research. Marketing Science, 14(3), 212-221. http://dx.doi. org/10.1287/mksc.14.3.G212 
Kerin, R. A., Varadarajan P. R., and Peterson. (1992). First-mover advantages: A synthesis, conceptual framew ork, and research propositions. Journal of Marketing, 56(4), 33-52. http://dx.doi.org/10.2307/1251985

Kvint, V. (1994). Don’t give up on Russian. Harvard Business Review, 72(2), 62-74.

Lanjouw, J., O., \& Cockburn I.. (2000). Do patents matter? Empirical evidence after GATT. NBER Working P aper, 7495.

Lerner, J. (2002). 150 years of patent protection. American Economic Review, 92(2), 221-225. http://dx.doi.org/ $10.1257 / 000282802320189294$

Lieberman, M. B. (1987). The learning curve, diffusion, and competitive strategy. Strategic Management Journ al, 8(5), 441-452. http://dx.doi.org/10.1002/smj.4250080504

Lieberman, M. B., \& Montgomery D. B. (1988). First-mover advantages. Strategic Management Journal, 9(1), 41-58. http://dx.doi.org/10.1002/smj.4250090706

Lieberman, M., B., \& Montgomery David B .(1998). First-mover (dis)advantages: Retrospective and link with the resource-based view. Strategic Management Journal, 19(12), 1111-1125. http://dx.doi.org/ 10.1002/(SI CI)1097-0266(1998120)19:12<1111::AID-SMJ21>3.0.CO;2-W

Lieberman, M. B., \& Asaba S. (2006). Why do firms imitate each other? Academy of Management Review, 3 1(2), 366-385. http://dx.doi.org/10.5465/AMR.2006.20208686

Lilien, G., L., \& Yoon E. (1990). The timing of competitive market entry: An exploratory study of new indus trial products. Management Science, 36(5), 118-138. http://dx.doi.org/10.1287/mnsc.36.5.568

Luo, Y. (1995). Business strategy, market structure, and performance of international joint ventures: The case of joint ventures in China. Management International Review, 35(2), 241-264.

Luo, Ya., \& Peng M. W. (1998). First mover advantages in investing in transitional economies. Thunderbird I nternational Business Review, 40(2), 141-163. http://dx.doi.org/ 10.1002/tie.4270400205

Mascarenhas, B. (1992). First-mover effects in multiple dynamic markets. Strategic Management Journal, 13(3), 237-243. http://dx.doi.org/10.1002/smj.4250130306

Mitchell, G. R., \& Hamilton W. F. (2007). Managing R\&D as a strategic option. Research-Technology Manage ment, 50(2), 41-50. http://dx.doi.org/10.1080/08956308.2007.11657429

Moser, P. (2005). How do patent laws influence innovation? Evidence from nineteenth-century world's fairs. $A$ merican Economic Review, 95(4), 1214-1236. http://dx.doi.org/10.1257/0002828054825501

Olausson, D., \& Berggren C. (2010). Managing uncertain, complex product development in high-tech firms: In search of controlled flexibility. R\&D Management Journal, 40(4), 383-399. http://dx.doi.org/10.1111/j.146 7-9310.2010.00609.x

Pan, Y.G., \& Chi P. (1999). Financial performance and survival of multinational corporations in China. Strate gic Management Journal, 20(4), 359-374. http://dx.doi.org/10.1002/(SICI)1097-0266(199904)20:4<359::AID$\mathrm{SMJ} 31>3.0 . \mathrm{CO} ; 2-9$

Patterson, W. C. (1993). First-mover advantage: The opportunity curve. Journal of Management Studies, 30(5), 759-777. http://dx.doi.org/10.1111/j.1467-6486.1993.tb00325.x

Qiu. L. D. (1997). On the efficiency of bertrand and cournot equilibria with product Journal of Economic The ory, 75(1), 213-229. http://dx.doi.org/10.1016/0022-0531(85)90086-9

Rhee, B. D., De Palma, A., Fornell C., \& Thisse Ja. F. (1992). Restoring the principle of minimum differenti ation in product positioning. Journal of Economics\& Management Strategy, 3(1), 475-505. http://dx.doi.or g/10.1111/j.1430-9134.1992.00475.x

Rhee, B. D. (2006). First-mover disadvantages with idiosyncratic consumer tastes along unobservable characteri stics. Regional Science and Urban Economics, 36(1), 99-117. http://dx.doi.org/10.1016/j.regsciurbeco.2005. 06.004

Robinson, W., T., Claes F., \& Mary S. (1992). Are market pioneers intrinsically stronger than later entrants? $S$ trategic Management Journal, 13(8), 609-624. http://dx.doi.org/10.1002/smj.4250130804

Robinson, W., T., Kalyanaram G., \& Urban G. L. (1995). Order of market entry: Established empirical genera lizations, emerging generalizations and future research." Marketing Science, 14(2), 212-221. http://dx.doi.o $\mathrm{rg} / 10.1287 / \mathrm{mksc}$.14.3.G212 
Schmalensee, R. (1982). Product differentiation advantages of pioneering brands. American Economic Review, 2 (3), 349-365.

Schnaars, S. P. (1994). Managing Imitation Strategies. New York: Free Press.

Shenkar, O. (1990). International joint ventures' problems in China: risks and remedies. Long Rang Planning, 23(3), 82-90. http://dx.doi.org/10.1016/0024-6301(90)90056-A

Smith, Roger. (2006). Modeling R\&D investment levels based on corporate financial data. Research-Technology Management, 49(6),16-22.

Stigler, G. J., \& Becker G. S. (1977). De gustibus non est disputandum. American Economic Review, 67(2), 7 6-90.

Suarez, F., \& Lanzolla G. (2005). The half-truth of first mover advantage. Harvard Business Review, 83(4), 1 21-127. http://dx.doi.org/10.1225/R0504J

Teece, D, J. (1986). Profiting from technological innovation: Implications for integration, collaboration, licensin $\mathrm{g}$ and public policy. Research Policy, 15(6), 285-305. http://dx.doi.org/10.1016/0048-7333(86)90027-2

Tellis, G., \& Golder P. (1996). First to market, first to fail? Real causes of enduring. Market leadership. Sloa $n$ Management Review, 37(2), 65-75.

Tubbs, M. (2007). The relationship between R\&D and company performance. Research-Technology Managemen $t$, 50(6), 23-30. http://dx.doi.org/10.1080/08956308.2007.11657470

Utterback, J. M. (1994). Mastering the Dynamics of Innovation. Harvard Business School Press, Boston.

Zhang, S., \& Markman A. B. (1998). Overcoming the early entrant advantage: The role of alienable and nonalienable differences. Journal of Marketing Research, 35(4), 413-426.

\section{(cc) EY}

This work is licensed under a Creative Commons Attribution 3.0 License. 